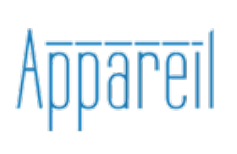

Appareil

11 | 2013

L'espace et l'architecture: état des lieux

\title{
Responsive Envelopes: the Fabric of Climatic Islands
}

Georges Teyssot

\section{OpenEdition}

1 Journals

\section{Electronic version}

URL: http://journals.openedition.org/appareil/1748

DOI: $10.4000 / a p p a r e i l .1748$

ISSN: 2101-0714

Publisher

MSH Paris Nord

\section{Electronic reference}

Georges Teyssot, « Responsive Envelopes: the Fabric of Climatic Islands », Appareil [Online], 11 | 2013, Online since 02 July 2013, connection on 30 July 2020. URL : http://journals.openedition.org/appareil/ 1748 ; DOI : https://doi.org/10.4000/appareil.1748

This text was automatically generated on 30 July 2020 .

\section{(c) $($ ) $(9)$}

Appareil est mis à disposition selon les termes de la Licence Creative Commons Attribution - Pas d'Utilisation Commerciale - Pas de Modification 4.0 International. 


\title{
Responsive Envelopes: the Fabric of Climatic Islands
}

\author{
Georges Teyssot
}

[...] Leibniz, the archaic inventor of contemporary algebra [...] discovered, not concurrently, but conjointly, a discipline that he called analysis situs and that we baptize topology, the sister science of the first one. [...] All those spaces [...] combine the open and the close, the exterior and the interior, the edge and the limit, the neighborhood and the adherence [...] all characteristic concepts of the numerous spaces of topology. [...] From there on, a whole program is drawn. One should draw graphs of paths and routes, [...] analyze nods, wheels, arborescence, a whole array of spatial tools, the technology of this discourse, and particular morphologies.

Michel Serres, "Discours et Parcours", 1974-1975. ${ }^{1}$

In his celebrated article "The New Brutalism" (1955), Reyner Banham proclaimed: "Topology becomes the dominant [...] discipline." During the 1960s and 1970s, the notions of topology (and of bio-topology) spread amid scientists and philosophers, as well as among artists and architects. For instance, the concept of "soft architecture" as promoted by Warren M. Brodey in 1967, who predicted the advent of intelligent, self organized environments, where the "convergence of data [is] necessary for maintaining a complex organism so that it changes noise into information, which allows the system to stabilize even as it changes." ${ }^{3} \mathrm{~A}$ soft environment is made of an "artificial man-machine system," a kind of cybernetic organism, a cyborg. Such an intelligent environment is called "soft architecture", so that "hard architecture will be replaced by the soft." ${ }^{5}$ 


\section{Soft and Hard}

2 In his essay "The Triumph of Software" (1968), Banham glossed over the mounting responsiveness associated with the notion of software. He offered an enthusiastic appraisal of the film Barbarella (1968), a good example of the interest shown for responsive environments. Such "soft" awareness was in contrast to a hardware related sensibility, best exemplified by Stanley Kubrick's film, 2001, also released in $1968 .{ }^{6}$ With this idea for an "aesthetic potential environment", the English cyberneticist Gordon Pask developed a cybernetic model for the relationship between viewer and artwork, as well as a unique case for showing the correlation between man and his environment. Pask was the resident cybernetician on Cedric Price's Fun Palace project [1961-1964], promoted by theater director Joan Littlewood, which mobilized the multiple notions of performance. ${ }^{7}$ Pask tells us that human beings investigate their environment for new situations, which they then learn to understand and control. This investigation of the environment, and assimilation of knowledge, together with instances of abstraction, qualify as "enjoyable forms of activity."

3 Famously, Pask conceived the "Colloquy of Mobiles", an installation created for the 1968 exhibition "Cybernetic Serendipity" held at the ICA in London. It was a reactive, educable, computer-based system composed of five mobiles. To give significance to the communication between the machines, Pask designed the "Colloquy of Mobiles" as a simulation of social system. ${ }^{9}$ The mobiles resembled Duchamp's frozen silhouettes, while they initiated to move and react. In the "Colloquy of Mobiles," the form of communication that Pask had conceived referred unmistakably to a sexual analogy: hung from the ceiling were two "males" mobiles and three "females" artifacts. This is a cybernetic version of the erotic encounter between a bride and her nine bachelors in Duchamp's Large Glass (1915-1923).The goal of communicating was to achieve this moment of satisfaction, and the mobiles learned to optimize their behavior to the point where this state could be reached with the least possible use of energy. With the help of flashlights and mirrors, the exhibition visitors could assume the roles of the mobiles and influence the learning process. After a phase of inactivity, the females (made of fiberglass) began to glow more intensely and the three males emitted a ray of light. When the ray of light struck the mirror inside the female mobile's structure, by way of rotating the mirror, she tried deflecting the ray back at the free-hanging light sensors above and below the male's aluminum body. ${ }^{10}$

4 In his seminal 1969 article "The Architectural Relevance of Cybernetics", published in Architectural Design, Gordon Pask argued that "architectural designs should have rules for evolution built into them if their growth were to be healthy." ${ }^{{ }_{11}} \mathrm{He}$ writes: "Nowadays there is a demand for system-oriented thinking", so there is an urgent need for a generalization of such thinking, the common constituents of which are "the notions of control, communication, and system. Hence, the generalization is no more nor less than abstract cybernetics interpreted as an overall architectural theory." ${ }^{12}$ With the help of "various computer-assisted design procedures", one will reach the concept of an environment with which the inhabitant cooperates and in which he can externalize his mental processes" 13 thus achieving a dialogue between the environment and its inhabitants. The dialogue can be refined and extended with the aid of modern techniques which allow us to weave the same patterns in terms of reactive environment. "If [...] the environment is malleable and adaptive the results can be very 
potent indeed." ${ }^{14} \mathrm{He}$ then mentions the works of Christopher Alexander, Nicholas Negroponte's Architecture Machine Group at MIT, and students of the AA School of Architecture. Then, in the same AD article, Pask adds that "the work of [Warren M.] Brodey and his group at the Environmental Ecology Laboratory [Boston, formerly at MIT] is a project on a[n] impressive scale." ${ }^{15} \mathrm{~A}$ Medical Doctor specializing in cybernetics and psychiatry, Brodey worked for the NASA Electronic Research Center, and was the first MD to be employed at the AI (Artificial Intelligence) Lab at MIT. It was the same Brodey who introduced the idea of a "bio-topology" in a 1971 article of the Radical Software magazine:

Infolding: imagine working through into depths with the help of a media that provides instantaneous feedback and thereby allows infolding with time, memory, energy, relation [...]. A topology that uses rhythms intermingling and flowing around and through each other would let us build walls secondarily, rather than as categorical dividers. TV networks do not have walls. ${ }^{16}$

5 Soon after, Pask will publish one of his most famous texts on CT (Conversation Theory) in Negroponte's 1975 volume on Soft Architecture. ${ }^{17}$ While computer screens on a PC will be organized in multitasking "Windows", it is the wall itself that might become a wallsize display, with windows that may open in various sizes. Negroponte would anticipate such condition:

[I]n the future, when you have massively high resolution and a wall size display, floor to ceiling and wall to wall, you may place your TV image on the screen as a function of where the plants are in the room, as opposed to the frame around some small screen. It's the whole wall. ${ }^{18}$

6 The concepts of "soft architecture" and of "bio-topology" are a prefiguration of a possible obliteration of the wall as a category. Accordingly, while infolding, or becoming a screen, the topologised wall eventually would lead to no wall.

\section{Inflected, Unfolded, Unframed}

7 During the 1980s, architects used mathematical notions, including those of the inflection point in differential calculus, in which the curvature changes signs (creating in some cases a saddle point), and those defined in geometry by the singularity theory, which is the study of the failure of manifold structure. In singularity theory the general phenomenon of points and sets of singularities is studied, as part of the concept that manifolds (spaces without singularities) may acquire special, singular points by a number of routes. In looking at classical statuary the folds of drapery are amongst the most obvious features. Other ways in which singularities occur is by degeneration of manifold structure. The presence of symmetry leads to consider orbifolds, which are manifolds that have acquired "corners" in a process of folding up resembling the creasing of a table napkin. The catastrophe theory of René Thom is another branch of singularity theory, which listed seven generic structures for these bifurcation geometries: catastrophes with potential functions of one active variable (fold, cusp, swallowtail, and butterfly); catastrophes with potential functions of two active variables (hyperbolic umbilic, elliptic umbilic, and parabolic umbilic).

Gilles Deleuze is guided in these concepts by the architect Bernard Cache, who defended his master thesis in science, titled Movable Ground. Furnishing the Territory, at the University of Paris VIII (Vincennes) in 1983. In the thesis' published version (English title: Earth Moves, 1995; French title: Terre Meuble, 1997), Cache argues that 
what surrounds us (i.e., the environment, or milieu) has to be perceived from the point of view of the "visible", beyond any function or purpose. He will then define three different, interlocking axes, describing various scales: "territories" which give rise to inflection; "objects" which are vector images; and, between the two, "buildings" that are the product of the frame ("cadre"). Cache proceeds to define territories as spaces subjected by the singularity of inflection: "inflection is the true atom of form [...] Space is thus no longer a juxtaposition of [valleys and] basins, but a surface of variable curvature." ${ }^{19}$ In such curved, inflected spaces, no one should think "that time flows, but that time varies. No settling is possible in such a landscape: variable curvature turns us into nomads." ${ }^{20}$ Settlement is achieved only through an unsettling: "[t]he reading of a landscape in relation to inflections leads us toward an experience of weightlessness." ${ }^{21}$ Form dissolves and "little by little, the waves make their way to surface. Shaped like a wave, inflection introduces the form of the vague [form], moving as a cluster of concavity." ${ }^{22}$ A graph frequently presents a number of critical points, including inflection points. Within real systems they represent points near which there is a disproportionate change in the overall state of the system relative to a small change in one or more variables. A good visualization would be that of a living being crawling across a piece of paper crumpled in the hand..$^{23}$

9 At smaller scale, buildings are the product of a set of framing operators. "Frames" are what architects usually call plans and sections; however, there are also a lot of other significant things, including not only the framing of the structure, but also the framing ("cadrage") of the view onto the surrounding. ${ }^{24}$ Architecture is the art of interlocking differently oriented frames, such as the wall, the window, the floor, the roof that envelops, and the slope section. Again, in What is Philosophy? (1991), Deleuze mentions profusely the outcome of Cache's thesis, quoting in length the proposition of an architecture made of intertwined framework:

Interlocking these frames or joining up all these planes [...] is a composite system rich in points and counterpoints. The frames and their joins (jonctions) hold the compound of sensations, hold up figures, and intermingle with their upholding, with their posture. Frames as sections are not coordinates; they belong to compounds of sensations whose faces, whose interfaces, they constitute. ${ }^{25}$

10 However, planes mustn't be kept forever as gigantic rational coordinates, but must be taken apart, in order to create new affects. The plane of composition needs to be also the place of vast line of flights, "that carries out a kind of deframing." ${ }^{26}$ Deleuze borrows the French term of "décadrage" from cinema-theorist Pascal Bonitzer, and such an "un-framing" permits to set off from the house-territory to town-cosmos, in order to "dissolve the identity of the place through variation of the earth" (in French, la Terre, i.e., Earth with a capital E). Now the building is traversed by a deframing power that opens architecture onto a plane of composition, on which can be actualized an infinite field of forces. ${ }^{27}$ Returning to Cache's volume, the line of flights that passes through the building is the geographic dimension, an absolute outside ("dehors") that crosses the inside, exceeding any attempt to interiority. Classical perspective was based on the painting-as-window, framing the view, or the subject matter. Now a deframed architecture unframes the frame. This can occur in many ways, including the metamorphosis of the frame into a screen.

11 If one could talk of a cinematographic device in architecture, "that allows for the passage from the frame to the screen," this happens "because architecture comprises a register of out-of-field images (images hors-champ) that is specific to it", i.e. the 
geographic span. ${ }^{28}$ In this manner, within the architectural framework, one has folded tour and detour, proximity and distance, finite and infinite, and outside onto the inside: "it is [an act of] furnishing (Fr., a-meublement) in the sense that furniture (meuble) is a property of earth." ${ }^{29}$ In French, the term "meuble" (furniture) refers to mobile objects or gear, as opposed to "immeuble" (building, construction), which bears the meaning of an immobile piece of equipment. Thus, for Cache, not only earth (as turf) is in motion, but the planet Earth becomes mobile, and moves. As Galileo said of the Earth, "yet, it moves" (in Italian, "eppur si muove"). While folding mobility and immobility, weightlessness and gravity (in Latin: celeritas and gravitas), outside and inside, architecture "functions as a topological operator." ${ }^{30}$ This also means that organism and milieu are related in no obvious (or natural) way, in as much as they belong to the domain of multiplicities and complexity. There is no such thing as a subject "thrown" into an environment (i.e., the Heideggerian Dasein); everything happens as if milieus were seeking one another and folding themselves onto an outside. ${ }^{31}$ Today, one has to learn to live on top of concave surfaces, at the tangent of a spline curve or on the top of NURBS surfaces, as in the structure erected by Jürgen Mayer H.'s Lazika Sculpture in Georgia (2012), a new kind of landmark able to span the geographic dimension, precisely as if milieus (weather, sky, horizon) were seeking one another, folding themselves onto an essential outside, becoming the fulcrum of vast lines of flights. ${ }^{32}$

\section{Lazika Pier Sculpture}

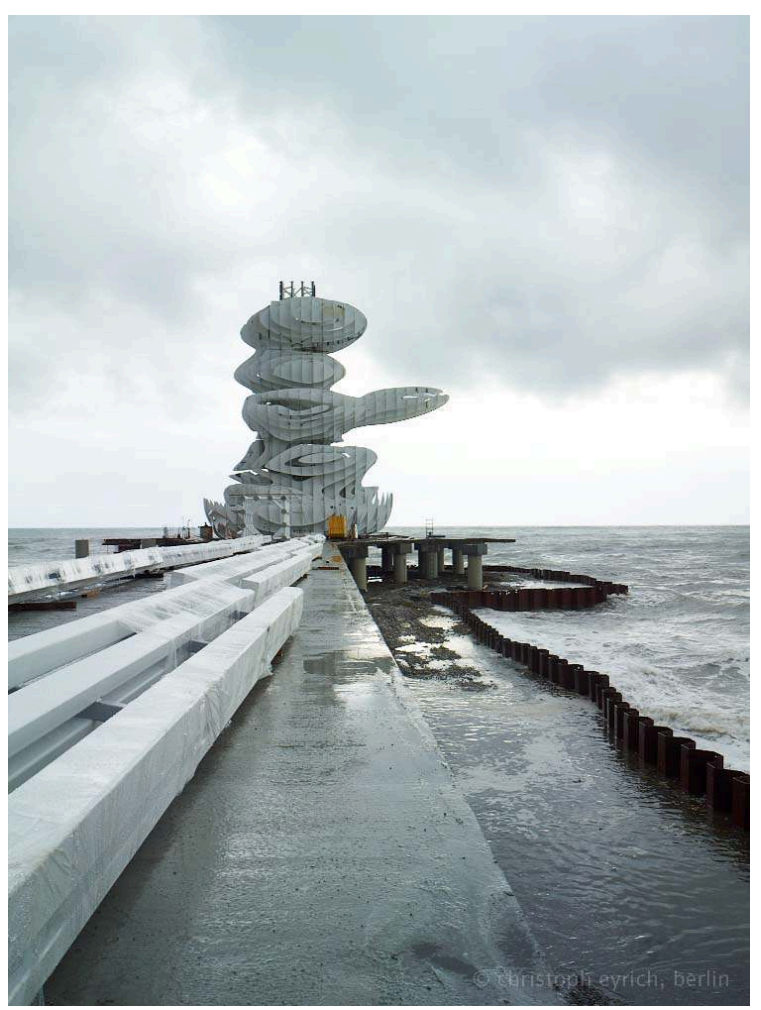

JÜRgEN MAYER H. ARCHITECTS, THE NEW LANDMARK FOR THE PIER OF LAZIKA, GEORgIA, 2012-2013 (C) PHOTO CHRISTOPH EYRICH, BERLIN; COURTESY OF: J. MAYER H. ARCHITECTS.

Deleuze's research on topological singularities will continue in his book The Fold: Leibniz and the Baroque (1988). One might ask what architects have discovered while reading 
Deleuze's interpretation of Leibniz. During the 1990s, while many architects were reading the English translation of Deleuze's Fold, Greg Lynn edited an issue of Architectural Design (1993) on the topic of Folding in Architecture. In his introduction, "Architecture Curvilinearity: The Folded, the Pliant, and the Supple", Lynn called for curvilinear forms. ${ }^{33}$ This invocation led to the provisional assertion of a "blob" architecture, the official birth of which seems to be marked by Lynn's subsequent article in ANY magazine (1996), in which he argued that tectonics was "out" and obsolete, while topology was "in" and sexy. ${ }^{34}$ Lynn also thumbed his nose at a series of personalities who were fighting rearguard battles, defending what remained of the idea of Semperian tectonics. Moreover, during the 1990s, new tools for 3-D modeling offered by numerous computer applications (Maya, Form*Z, Rhino) would make it possible for architects to literally multiply the folds in their projects. Deleuze argued that Leibniz's monad is a folded membrane, a receiver organ for picking up the world. But it is also an enveloping substance, a sort of skin. ${ }^{35}$

Deleuze draws the monad in the form of a two-storey, baroque house. The monad is made of two floors, in which "the upper level is closed, as a pure inside without an outside, a weightless, closed interiority, its walls hung with spontaneous folds that are now only those of a soul or a mind." ${ }^{36}$ The folds of the brain's circumvolutions are baroque works of art and the monad is organized according to two vectors, one deepening down and the other rising as a thrust toward the upper region. ${ }^{37}$ The two vectors, one metaphysical, the other physical, comprise a similar world: they live "in a similar house." ${ }^{38}$ If the monad exists as an absolute interiority and materializes as an inner surface with only one side, it nonetheless presents another side. Actually, for Deleuze, the monad has "a minimum of outside, a strictly complementary form of outside." ${ }^{39}$ There appears to be an incongruity between the pure, inside condition and some outside. For Deleuze, topology can resolve the apparent contradiction as partition, a supple and adherent membrane, forms a fold, a torsion that provides "the exterior or outside of its own interiority." ${ }^{40}$

\section{Metastable Systems}

14 Today, as Deleuze suggested, one issue remains: the question of how to live in the world. The "topological" condition of contemporary living does not allow the difference between inside and outside to survive. It has erased, or at least shifted, the limits between private and public: "what has changed now is the organization of the home and its nature." ${ }^{41}$ Read by Deleuze, the concept of monad raises the issue of the wall and the window. Does the monad have no windows ("die Monaden zwar keine Fenster", Gottfried Wilhelm Leibniz) ? Or do they have some kind of aperture ("aber eine Monade hat Fenster", according to Edmund Husserl)? Or, like in a monad, "the true has no windows" ["Das Wahre hat keine Fenster"] according to Walter Benjamin? ${ }^{42}$ Probably, it is the notion of a topological fold that explains what coalesce interior and exterior, and how inside and outside unfurl by a spatial twist that exposes the exteriority of the interior, and reveals the extimity of the intimate. Perhaps Peter Sloterdijk is right when he observes that the myriads of bubbles (i.e., monads as dyads) that inhabit our world in the shape of foam (Schäume), may be presenting no doors and "only blind windows on which one has painted an exterior." ${ }^{43}$ Today's monads are can be compared to a mobile home, with windows half transparent, half opaque, on which a 
simulated landscape has been painted, with enormous pixels imitating a the granularity of a screen. In concluding his book The Fold, Deleuze points out that, in the future, we will need "to overtake monadology with a "nomadology'." ${ }_{44}^{4}$ This paradoxical situation - one in which a closed space restores to us the outside of our interiority describes the condition of our screens, those catoptric boxes that are now part of our ever more interactive environment.

Criticism of the substantial subject (the "me" of psychology, the "I" of metaphysics) occurred through exploration of new impersonal individuations, those pre-individual singularities that Deleuze effectively discovered in Gilbert Simondon's main doctoral thesis, defended in 1957 and published in part in 1964 as L'Individu et sa genèse physicobiologique (Individuation and its Physical-Biological Genesis). ${ }^{45}$ For Deleuze, Simondon's essay offered the first rationalized theory of impersonal and pre-individual singularities. Breaking with stable ontologies of substance, Simondon formulates a philosophy of individuation in becoming, at the center of which the human subject occupies only a limited place. ${ }^{46}$ The pre-individual is "a being who is more than a unit." Simondon writes: "The pre-individual being is a being in whom there are no phases; a being in whose center individuation takes place is a being in whom a resolution appears through the being's distribution into phases, thus putting everything in a state of becoming." ${ }^{47}$ After Friedrich Nietzsche, Henri Bergson, Gaston Bachelard and Georges Canguilhem, Simondon was to contribute to an undermining of the paradigm of the individual being by re-posing the problem in terms of the whole set of processes, the forging and emergence of the real, that lead to individuation. "Individuation is the operation itself of the pre-individual; it is the pre-individual itself in operation." ${ }^{48}$ To describe this phenomenon, one must be able to reconstitute pre-individual nature as the source of all existence, the principle of genesis: nature before things and individuals, the source of their begetting. To the question, "What is an individual?" Simondon replies:

One cannot, strictly speaking, talk about an individual, but only about individuation; we need to go back to the activity, to the genesis, instead of trying to apprehend the fully-formed being in order to discover the criteria by which we know whether he is an individual or not. The individual is not a being but an act, and a being is an individual as an agent of this act of individualization by which he manifests himself and exists. ${ }^{49}$

16 What one is being asked to do is to consider nature not as an a priori, but as a construction-in-becoming. Pre-individual nature has to be constructed to take account of all processes. The transition from nature to the individual can be constructed by broadening the concept of nature to the whole set of realities prior to individuation, whatever the level of complexity, and by managing to define unbalanced systems, known as "metastable" systems. The notion of "metastability" was taken from the notion of entropy, specific to the cyberneticist Norbert Wiener. ${ }^{50}$ Metastability is the concept Simondon creates to describe the phenomena of entropy specific to thermodynamics, to Wiener's cybernetics, and to the theory of information, and which represents a system that has not yet exhausted its potential difference, with an increase in order or information (Erwin Schrödinger's negative entropy or Léon Brillouin's negentropy). ${ }^{51}$

One needs to see nature as "the reality of the possible" 52 - that is, as what is likely to cause something to exist. This reality of the possible corresponds to a "real potential" that distinguishes it from both the possible and the virtual, suggesting that the notion 
of virtuality be replaced by the notion of "the metastability of a system". ${ }^{33}$ Simondon makes clear in his complementary thesis of 1958, Du mode d'existence des objets techniques (On the mode of existence of technical objects), that "the potential is one of the forms of the real, as completely as the actual is. The potentials of a system constitute its power of becoming without deteriorating", by resisting the phenomenon of thermodynamic entropy ${ }^{54}$ These potentials "are not the simple virtuality of future states, but a reality that drives them to be. Becoming is not the actualization of a virtuality [...] but the operation of a system having potentials in its reality." ${ }^{55}$ Simondon consequently establishes an important distinction between the possible, the actual, and the virtual: the possible doesn't "contain" the actual already, just as nature does not include all beings virtually, and the latter are not the realization of a given nature. As mentioned before, the possible does not contain the actual already before it emerges, for every individual is an event.

Simondon's bio-philosophy leads to the observation that supple, soft materials are more resistant than hard matter, like skin in nature. In the case of inflatable buildings, the traditional divide between interior and exterior tends to disappear. The flexible membrane of air-filled volume acts as the skin of a living apparatus plunged in a given milieu. Such an atmospheric architecture creates climatic islands that operate as controlled, homeostatic systems. Today there are various modeling digital tools that can analyze all the data's system. For instance, System Dynamics software permits the study of the behavior of complex systems over time. What is being challenged here is the drastic opposition between interior and exterior, including their categorical existence. Like with the pre-individuation of an egg, a cell, or a crystal, such systems are complex, unbalanced and metastable entities, performing like literal environments. Conceptually, walls, windows and doors, go through a profound alteration, while they are replaced by transparent, opaque and mobile surfaces. Architecture's foundation abandons the gravity of the solid wall and becomes a sentient envelope. The levity of the skin replaces the ontological walls' weight, so that architecture becomes fluid and ephemeral, nomad and transportable..$^{56}$ This "air architecture" is well exemplified by some of Toyo Ito's metaphoric, blurred projects, such as the Tower of Winds (Yokoyama, 1986), or in Kengo Kuma's Breathing Architecture (2008). ${ }^{57}$ What is being inaugurated here is an atmospheric architecture, created by quasi invisible membranes or meshes, capable of capturing the intensity of forces and controlling the energies that animate matter.

In Deleuze, that which effects the passage of the virtual into the actual is the intensity (or intensive quality) whose essential activity is that of individuation. ${ }^{58}$ Deleuze's intensity is best understood after considering the concept of individuation, which Deleuze takes from simondon. Simondon uses information theory to describe individuation in physical and biological systems, showing that traditional distinctions between form and matter, individual and milieu, animate and inanimate, must be reconceived in terms of information in order to take account of the reality of the process of individuation..$^{59}$ Moreover, Simondon proposes to stretch individuation beyond the individual being, and extend it to a broader nature, to whose identity it contributes. Thus, Simondon speaks of individual-milieu, a hybrid form, loaded with potentialities and singularities. The individual, arising from a situation of genesis, seems to be finally just a kind of crease, a fold that, while unfolding, would unfurl the 
whole of nature. To view milieu, itself the result of individuation, one is obliged to consider the individual and its environment.

\section{Membrane, Crystal, Milieu}

20 formulate hypotheses on a chrono-topology. ${ }^{60}$ While filtering what passes through, and preventing the access to other bodies or substances, the membrane is polarized. ${ }^{61}$ Therefore, milieu connotes the specific sense of a third biological term, neither inside nor outside, placed halfway in the middle. ${ }^{62}$ Deleuze was inspired by Simondon's theory of the membrane, while attempting to construe his assumptions about pre-individual singularities. ${ }^{63}$ In The Logic of Sense (1969), Deleuze notes that in membranes "the internal and the external, depth and height, have biological value only through this topological surface of contact." ${ }^{64}$ This will lead to considerations about the folded surface of the cell, allowing Deleuze to assign a biological value to Paul Valéry's famous statement: "The deepest is the skin." ${ }^{65}$ Then, Deleuze inserts a quotation extracted from Simondon's thesis: "The entire content of the internal space is topologically in contact with the content of external space at the limits of the living." ${ }^{66}$ Simondon's conception presupposes the existence of a pre-individual reality, because "what appears in the individuation is not only the individual, but the couple individual-milieu." ${ }^{67}$

21 Another example of individuation is the process of crystallization: the passage of a substance from a metastable, amorphous state to a stable, crystalline one. Individuation, therefore, precedes the individual. Simondon argues that the simple model of crystallization may be used to understand the process of individuation throughout physical and biological systems. The difference between animate and inanimate matter is that animate matter manages to sustain certain metastable states that allow a perpetual individuation in the organism. We perceive a distinction between matter and form, organism and environment, species and individual, but these are merely manifestations of a single process of becoming, metastable and preindividual, which constitutes the real. ${ }^{68}$ In Deleuze's terms, a metastable substance is a difference in itself, and individuation is a process in which difference differentiates itself.

In conclusion, topology and chronology coincide in the individuation of the living: they are not a priori forms, but the dimensionality of living while it is individualizing. Thus, for Simondon, are met the conditions, so as to think morphogenesis. ${ }^{69}$ As a result, it is the genetic processes analyzed by Simondon - brick, membranes or crystals, for example - that allow for rethinking spatial categories, such as inside and outside, depth and height, transparent and opaque, top and bottom, front and rear, light and heavy, mobile and immobile, fast and slow, smooth and striated, and so forth. Suddenly, basic architecture (basement and attic, wall and partition, doors and windows, floor and ceiling, ground and roof) sees its meaning entering into a baroque metamorphosing, and transmuting into a topological surface of contact.

Topology help understand space in terms of properties of connectedness and invariance under transformation. With the new level of computer 3-D modeling, architects have engaged with non orientable surfaces (those with no clear inside and outside). Surface in topology is called a two-dimensional manifold. Topologically homogenous (equivalent) surfaces may be very different in shape. ${ }^{70}$ It is possible to 
model surfaces that could change, stretch, adopt free-form curvatures, or conform to a geometrical rationale without losing their integrity. ${ }^{71}$ While becoming "smart", the wall has been mutating, beginning with Charles M. ("Chuck") Eastman's adaptive conditional architecture (1975), and progressing with John Frazer's evolutionary, paskian approach to design at the AA (1995), and Philip Beasley responsive materials (2007), or the distributed intelligence of the EFTE facades in the Media-TIC building in Barcelona (2010) by Enric Ruiz-Geli (Cloud 9), where the soft becomes hard. Sloterdijk's Spheres (Bubbles, Globe, Foam), the three volumes exploration of how to dwell in spaces represent a significant topological turn in contemporary thinking. ${ }^{72}$ Topology investigates the fabric of a space together with points, regions, neighborhood, inside and outside, limit. Topology will help develop Sloterdijk's climatic islands, protected by artificial, intelligent, sentient and responsive envelopes.

\section{BIBLIOGRAPHY}

Banham Mary, et al. (eds.), A Critic Writes: Essays by Reyner Banham, Berkeley, University of California Press, 1996, pp. 7-15.

Banham Reyner, “The New Brutalism”, The Architectural Review, vol. 118, 1955, pp. 354-361.

Banham Reyner, “The Triumph of Software” [1968], in Penny Sparke (ed.), Design by Choice, London, Academy Editions, 1981, pp. 136-137.

Barthélémy Jean-Hugues, Simondon ou l'Encyclopédisme génétique, Paris, PUF, 2008.

Bogue Ronald, Deleuze and Guattari, London/New York, Routledge, 1989.

Bredekamp Horst, Die Fenster der Monade: Gottfried Wilhelm Leibniz' Theater der Natur und Kunst, Berlin, Akademie, 2008.

Brodey Warren M., "The Design of Intelligent Environments: Soft Architecture”, Landscape, vol. 17, nº 1, 1967, pp. 8-12.

Brodey Warren M., “Biotopology 1972”, Radical Software, vol. 1, nº 4, 1971, pp. 4-7, accessible online at: http://www.radicalsoftware.org/volume1nr4/pdf/VOLUME1NR4_art02.pdf

Burry Jane, Burry Mark, The New Mathematics of Architecture, London, Thames \& Hudson, 2010.

Cache Bernard, Earth Moves: The Furnishing of Territories, Anne Boyman (trans.), Michael Speaks (ed.), Cambridge (Mass.)/London, M.I.T. Press, 1995.

Charre Alain, Hans-Walter Müller et l'architecture de la disparition, Paris, Archibooks/Sautereau, 2012.

Chateau Jean-Yves, Le Vocabulaire de Simondon, Paris, Ellipses, 2008.

Deleuze Gilles, The Fold: Leibniz and the Baroque, Tom Conley (trans.), Minneapolis, University of Minnesota Press, 1993.

Deleuze Gilles, Guattari Félix, What is philosophy?, Hugh Tomlinson and Graham Burchell (trans.), New York/Chichester, Columbia University Press, 1994. 
Deleuze Gilles, “On Gilbert Simondon”, in Gilles Deleuze, Desert Islands: and Other Texts, 1953-1974, Los Angeles/New York, Semiotext(e), 2004, pp. 86-98.

Deleuze Gilles, The Logic of Sense, London, Continuum, 2004.

Fischer Volker, Schneider Ulrich (eds.), Kengo Kuma: Breathing architecture: The Teahouse of the Museum of Applied Arts Frankfurt: Das Teehaus des Museums für Angewandte Kunst Frankfurt, Basel/ Boston, Birkhäuser, 2008.

Grobman Yasha J., Neuman Eran (eds.), Performalism: Form and Performance in Digital Architecture, Londres/New York, Routledge, 2012.

Haque Usman, “The Architectural Relevance of Gordon Pask”, in Lucie Bullivant (ed.), Architectural Design: 4dsocial: Interactive Design Environments, vol. 77, $\mathrm{n}^{\circ}$ 4, 2007, pp. 80-88.

Lynn Greg (ed.), Folding in Architecture, with new introductions by Greg Lynn and Mario Carpo, Chichester, Wiley-Academy, 2004; a facsimile, based on Architectural Design, vol. 63, n 3-4, 1993. Lynn Greg, "Blobs (or Why Tectonics is Square and Topology is Groovy)", ANY, n 14, 1996, pp. 58-61.

Negroponte Nicholas, “Iconographics”, in Being Digital, London, Hodder \& Stoughton, 1995, in Neil Spiller (ed.), Cyber Reader: Critical Writings for the Digital Era, London, Phaidon, 2002, pp. 258-260.

Pask Gordon, "The Colloquy of Mobiles", in Jasia Reichardt (ed.), Cybernetic Serendipity: the Computer and the Arts, New York, Praeger, 1968, pp. 34-35.

Pask Gordon, “The Architectural Relevance of Cybernetics”, Architectural Design, vol. 39, 1969, pp. 494-496.

Pask Gordon, “A Comment, a Case History and a Plan”, in Reichardt Jasia (ed.), Cybernetics, Art and Ideas, London, Studio Vista, 1971, pp. 76-99.

Pask Gordon, “Aspects of Machine intelligence”, in Nicholas Negroponte, Soft Architecture Machines, Cambridge (Mass.)/London, M.I.T. Press, 1975, pp. 7-31.

Petit Victor, “L'individuation du vivant [...]”, in Jean-Hugues Barthélémy (ed.), Cahiers Simondon Numéro 1, Paris, l'Harmattan, 2009, p. 47-75.

Sauvagnargues Anne, Deleuze : l'empirisme transcendental, Paris, PUF, 2010.

Serres Michel, « Discours et Parcours », in L’Identité : séminaire interdisciplinaire, 1974-1975, Claude Lévi-Strauss (dir.), Paris, Grasset (Figures), 1977, p. 25-49.

Simondon Gilbert, Du mode d'existence des objets techniques, Paris, Aubier, 1958.

Simondon Gilbert, L'Individuation à la lumière des notions de forme et d'information, Grenoble, Millon, 2005. This first complete edition combines L'Individu et sa genèse physico-biologique, Paris, 1964 and L'Individuation psychique et collective, Paris, 1989.

Simondon Gilbert, “The Genesis of the Individual”, in Jonathan Crary, Sanford Kwinter (eds.), Incorporations, New York, Zone, 1992, pp. 297-319; Arne De Boever, et al. (eds.), Gilbert Simondon: Being and Technology, Edinburgh, Edinburgh University Press, 2012.

Sloterdijk Peter, Sphères. III, Écumes : sphérologie plurielle [Sphären. III, Schäume, Frankfurt-am-Main, Suhrkamp, 2004], Olivier Mannoni (trad.), Paris, Hachette littératures, 2006.

Teyssot Georges, “Architecture as Membrane”, in Reto Geiser (ed.), Explorations in Architecture: Teaching, Design, Research, Basel, Birkhäuser, 2008, pp. 166-175; version française, “Architecture 
comme Membrane": http://www.designexplorations.org/pages/resources/uploads/131/ Teyssot_FR.pdf

Teyssot Georges, "The Membrane and the Fold", in Aaron Sprecher, Shai Yeshayahu, and Pablo Lorenzo-Eiroa (eds.), LIFE in:formation, On Responsive Information and Variations in Architecture, ACADIA 2010 conference proceedings, New York, 2010, pp. 26-31.

Teyssot Georges, Bernier-Lavigne Samuel, "Forme et information : Chronique de l'architecture numérique”, in Alain Guiheux (ed.), Action Architecture, Paris, Éd. de la Villette, 2011, p. 49-87.

Teyssot Georges, Jacques Olivier, "In the Shade of Algorithms", in J. Mayer H., Metropol Parasol, Andres Lepik, Andre Santer (eds), Ostfildern, Hatje Cantz, 2011, pp. 77-83.

Teyssot Georges, “Time-Crystal: Information and Entropy”, AI (Architecture and ideas) vol. XI, "Entropic Territories", 2011, pp. 67-83.

Topology, Tate Modern, London, lectures series, Saturday 5 November 2011 - Saturday 16 June 2012, accessed online, http://www.tate.org.uk/whats-on/tate-modern/eventseries/topology

Valéry Paul, “L'Idée fixe” [1931], in Paul Valéry, Cuuvres II, Paris, Gallimard, 1960.

\section{NOTES}

1. Michel Serres, "Discours et Parcours ", in L'Identité: séminaire interdisciplinaire, 1974-1975, Claude Lévi-Strauss (dir.), Jean-Marie Benoist, et al., Paris, Grasset (Figures), 1977, p. 25-49. Translated from French to English by the author.

2. Reyner Banham, “The New Brutalism”, The Architectural Review, vol. 118, 1955, pp. 354-361, esp. p. 361; repr. in Mary Banham, et al. (eds.), A Critic Writes: Essays by Reyner Banham, Berkeley, 1996, pp. 7-15.

3. Warren M. Brodey, "The Design of Intelligent Environments: Soft Architecture", Landscape, vol. 17, $\mathrm{n}^{\circ} 1,1967$, pp. 8-12, esp. p. 12.

4. Ibid., p. 12 .

5. Ibid.

6. Reyner Banham, “The Triumph of Software”, in Penny Sparke (ed.), Design by Choice, London, Academy Editions, 1981, pp. 136-137 (originally published in New Society, 31, October 1968).

7. Yasha J. Grobman, Eran Neuman (eds.), Performalism: Form and Performance in Digital Architecture, London/New York, Routledge, 2012, pp. 22-23.

8. Our text quotes in full: Margit Rosen, in Media, art, net, accessible online at: http://www.medienkunstnetz.de/works/colloquy-of-mobiles/

9. Again, we follow Margit Rosen, in Media, art, net, ibid., and Gordon Pask, "Colloquy of mobiles", in Jasia Reichardt (ed.), Cybernetic Serendipity: the Computer and the Arts, New York, Praeger, 1968, pp. 34-35.

10. Again, see Margit Rosen, in Media, art, net, ibid., and Gordon Pask, "A Comment, a Case History and a Plan", in Jasia Reichardt (ed.), Cybernetics, Art and Ideas, London, Studio Vista, 1971, pp. 76-99.

11. Gordon Pask, "The Architectural Relevance of Cybernetics", Architectural Design, vol. 39, 1969, pp. 494-496, see 495.

12. Ibid., p. 496. See also Usman Haque, "The Architectural Relevance of Gordon Pask", in Lucie Bullivant (ed.), Architectural Design: 4dsocial: Interactive Design Environments, vol. 77, $\mathrm{n}^{\circ} 4,2007$, pp. 80-88.

13. Ibid., p. 496.

14. Ibid. 
15. Ibid., p. 496.

16. Warren M. Brodey, "Biotopology 1972”, Radical Software, vol. 1, nº 4, 1971, pp. 4-7, accessible online at: http://www.radicalsoftware.org/volume1nr4/pdf/VOLUME1NR4_art02.pdf (accessed October 2, 2012).

17. Gordon Pask, "Aspects of Machine intelligence", in Nicholas Negroponte, Soft Architecture Machines, Cambridge (Mass.)/London, M.I.T. Press, 1975, pp. 7-31.

18. Nicholas Negroponte, "Iconographics”, in Being Digital, London, Hodder \& Stoughton, 1995; in Neil Spiller (ed.), Cyber Reader: Critical Writings for the Digital Era, London, Phaidon, 2002, pp. 258-260, p. 260.

19. Bernard Cache, Earth Moves: The Furnishing of Territories, Anne Boyman (trans.), Cambridge (Mass.)/London, M.I.T. Press, 1995, p. 41.

20. Ibid.

21. Ibid., p. 44.

22. Ibid., p. 51, our edited transl.

23. Jane Burry, Mark Burry, The New Mathematics of Architecture, London, Thames\& Hudson, 2010, p. 265.

24. Ibid., p. 56-65.

25. Gilles Deleuze, Félix Guattari, What is philosophy?, Hugh Tomlinson and Graham Burchell (trans.), New York/Chichester, Columbia University Press, 1994, p. 187.

26. Ibid.

27. Ibid., p. 188.

28. Cache, Earth Moves, (note 19), p. 70.

29. Ibid., p. 71.

30. Ibid., p. 72.

31. Ibid., p. 81.

32. See Georges Teyssot, "The Membrane and the Fold", in Aaron Sprecher, Shai Yeshayahu, and Pablo Lorenzo-Eiroa (eds.), LIFE in:formation, On Responsive Information and Variations in Architecture, ACADIA 2010 conference proceedings, New York, 2010, pp. 26-31; Georges Teyssot, with Olivier Jacques, "In the Shade of Algorithms", in J. Mayer H., Metropol Parasol, Andres Lepik, Andre Santer (eds), Ostfildern, Hatje Cantz, 2011, pp. 77-83; Georges Teyssot, Samuel Bernier-Lavigne, "Forme et information: Chronique de l'architecture numérique", in Alain Guiheux (ed.), Action Architecture, Paris, Éd. de la Villette, 2011, pp. 49-87.

33. Greg Lynn (ed.), Folding in Architecture, with new introductions by Greg Lynn and Mario Carpo, rev. ed., Chichester, Wiley-Academy, 2004; a facsimile, based on Architectural Design, vol. 63, $\mathrm{n}^{\circ}$ 3/4, 1993.

34. Greg Lynn, "Blobs (or Why Tectonics is Square and Topology is Groovy)", ANY, n 14, 1996, pp. 58-61.

35. See Gilles Deleuze, The Fold: Leibniz and the Baroque, Tom Conley (trans.), Minneapolis, University of Minnesota Press, 1993, p. 5.

36. Ibid., p. 29.

37. Ibid.

38. Ibid.

39. Ibid., p. 111.

40. Ibid.

41. Ibid., p. 158.

42. Horst Bredekamp, Die Fenster der Monade: Gottfried Wilhelm Leibniz' Theater der Natur und Kunst, $2^{\text {nd }}$ ed., Berlin, Akademie, 2008.

43. Peter Sloterdijk, Sphères. III, Écumes: sphérologie plurielle, Olivier Mannoni (transl.), of : Id., Sphären. III, Schäume, Paris, Hachette littératures, 2006, p. 55, our translation.

44. Deleuze, The Fold, (note 35), p. 226. 
45. See Gilbert Simondon, L'Individuation à la lumière des notions de forme et d'information, Grenoble, Millon, 2005. This first complete edition combines L'Individu et sa genèse physico-biologique (Paris, 1964) and L'Individuation psychique et collective (Paris, 1989).

46. See Anne Sauvagnargues, Deleuze. L'empirisme transcendantal, Paris, PUF, 2010, pp. 26-27.

47. Gilbert Simondon, L'Individuation (note 31), p. 25, our translation; see Jean-Yves Chateau, Le Vocabulaire de Simondon, Paris, Ellipses, 2008, p. 48.

48. Jean-Yves Château, Le Vocabulaire de Simondon, (note 33), p. 49, our translation.

49. Gilbert Simondon, L'Individuation (note 31), p.191, our translation; see Jean-Hugues Barthélémy, Simondon ou l'Encyclopédisme génétique, Paris, PUF, 2008, pp. 18-19.

50. Jean-Hugues Barthélémy, Simondon ou l'Encyclopédisme génétique (note 35), p. 20.

51. Anne Sauvanargues, Deleuze : l'empirisme transcendantal (note 32), p. 243. See Georges Teyssot, "Time-Crystal: Information and Entropy", AI (Architecture and ideas), vol. XI, "Entropic Territories", 2011, pp. 67-83.

52. Gilbert Simondon, L'Individuation, (note 31), p. 305, our translation.

53. Ibid., p. 313, our translation; Jean-Hugues Barthélémy, Simondon ou l'Encyclopédisme génétique (note 35), p. 21.

54. Gilbert Simondon, Du mode d'existence des objets techniques, Paris, Aubier, 1958 ; repr. with an added preface by John Hart and a postface by Yves Deforge, Paris, 1989/2001, pp. 155-156, our translation.

55. Ibid., our translation.

56. Alain Charre, Hans-Walter Müller et l'architecture de la disparition, Paris, Archibooks/Sautereau, 2012, p. 12, 26, 36-39, 41, 44, 62.

57. Volker Fischer, Ulrich Schneider (eds.), Kengo Kuma: Breathing architecture: The Teahouse of the Museum of Applied Arts Frankfurt: Das Teehaus des Museums für Angewandte Kunst Frankfurt, Basel and Boston, Birkhäuser, 2008.

58. See Ronald Bogue, Deleuze and Guattari, London/ New York, Routledge, 1989, p. 61.

59. See Gilbert Simondon, "The Genesis of the Individual", in Jonathan Crary, Sanford Kwinter (eds.), Incorporations, New York, Zone, 1992, pp. 297-319; Arne De Boever, et. al. (eds.), Gilbert Simondon: Being and Technology, Edinburgh, Edinburgh University Press, 2012.

60. Gilbert Simondon, L'individuation (note 31), p. 225, our translation.

61. See ibid., our translation; see Georges Teyssot, "Architecture as Membrane", in Reto Geiser (ed.), Explorations in Architecture: Teaching, Design, Research, Basel, Birkäuser, 2008, pp. 166-175; version française, “Architecture comme Membrane", in Explorations in Architecture :

http://www.designexplorations.org/pages/resources/uploads/131/Teyssot_FR.pdf

62. See Victor Petit, "L’individuation du vivant [...]", in Jean-Hugues Barthélémy (éd.), Cahiers Simondon - Numéro 1, Paris, l'Harmattan, 2009, pp. 47-75, esp. p. 57.

63. Gilles Deleuze, "On Gilbert Simondon", in Gilles Deleuze, Desert Islands and Other Texts, 19531974, Los Angeles/ New York, Semiotext(e), 2004, pp. 86-98; Anne Sauvagnargues, Deleuze: l'empirisme transcendantal (note 32), pp. 26-28.

64. Gilles Deleuze, The Logic of Sense, London, Continuum, 2004, pp. 119.

65. Paul Valéry, «L'Idée fixe » [1931], in Paul Valéry, CEuvres II, Paris, Gallimard, 1960, p. 215.

66. Gilbert Simondon, L'individu et sa genèse physico biologique, Paris, 1964, p. 260-264 ; cited by Deleuze, The Logic of Sense (note 48), p. 119.

67. Gilbert Simondon, L'individuation (note 31), p. 24-25, our translation; Jean-Hugues Barthélémy, Simondon ou l'Encyclopédisme génétique (note 35), p. 41.

68. See Ronald Bogue, Deleuze and Guattari (note 43), p. 62.

69. Ibid., p. 228.

70. Jane Burry, The New Mathematics of Architecture, pp. 16-18.

71. Ibid., pp. 159-161. 
72. Topology, Tate Modern, London, lectures series, Saturday 5 November 2011 - Saturday 16 June 2012, accessed online, http://www.tate.org.uk/whats-on/tate-modern/eventseries/topology

\section{ABSTRACTS}

In 1967, Warren M. Brodey invented the concept of "soft architecture", an obliteration of the wall as a category. In a 1971 article titled "Biotopology", he wrote "Infolding: imagine working through into depths with the help of a media that provides instantaneous feedback and thereby allows infolding with time, memory, energy, relation... TV networks do not have walls...." A Medical Doctor specializing in cybernetics and psychiatry, Brodey worked for the NASA Electronic Research Center, and was the first MD to be employed at the AI (Artificial Intelligence) Lab at MIT. For Gilbert Simondon, topology and chronology coincide in the individuation of the living: they are not a priori forms, but the dimensionality of living while it is individualizing. Thus, for Simondon, are met the conditions, so as to think morphogenesis. As a result, it is the genetic processes analyzed by Simondon - brick, membranes or crystals, for example - that allow for rethinking spatial categories. Suddenly, basic architecture (wall and partition, floor and ceiling) sees its meaning entering into a baroque metamorphosing, and transmuting into a topological surface of contact.

En 1967, Warren M. Brodey inventait le concept de « soft architecture » qui supprimait le mur en tant que catégorie. Dans un article de 1971 intitulé « Biotopologie », il écrit : « Imaginez effectuer une recherche approfondie à l'aide d'un media qui vous fournit des informations instantanées et qui par conséquent permet des retours dans le temps, la mémoire, l'énergie, les liens... Les réseaux de télévision n'ont pas de murs... ». Docteur en médecine spécialisé dans la cybernétique et la psychiatrie, Brodey a travaillé pour le Centre de Recherche Électronique (ERC) de la NASA et fut le premier docteur en médecine à être employé par le Laboratoire d'Intelligence Artificielle (CSAIL) du MIT. Pour Gilbert Simondon, la topologie et la chronologie procèdent de l'individuation du vivant : il n'existe pas de formes a priori, mais une dimensionnalité du vivant qui s'établit au cours de son processus d'individuation. C'est ainsi que sont réunies les conditions qui permettent de penser la morphogenèse selon Simondon. En conséquence, ce sont les processus génétiques analysés par Simondon (les briques, les membranes et les cristaux, par exemple) qui permettent de repenser les catégories spatiales. Soudain, l'architecture élémentaire (murs, cloisons, sols et plafonds) voit son sens entrer dans une métamorphose baroque et se transformer en une surface de contact topologique.

\section{AUTHOR}

\section{GEORGES TEYSSOT}

Georges Teyssot is Professor at Laval University's School of Architecture in Quebec. He has previously taught history and theory at the Istituto Universitario di Architettura of Venice, Italy and at Princeton University's School of Architecture. 